\title{
EFEK ANTIMIKROBA EKSTRAK RIMPANG TEMULAWAK (Curcuma xanthorrhiza) TERHADAP PERTUMBUHAN Staphylococcus aureus
}

\author{
Ardiana Retno Mashita
}

Fakultas Kedokteran Universitas Muhammadiyah Malang, J1. Bendungan Sutami No. 188A, Malang, 65145, Indonesia, 0341-551149

\begin{abstract}
ABSTRAK
Efek Antimikroba Ekstrak Rimpang Temulawak (Curcuma xanthorrhiza) Terhadap Pertumbuhan Staphylococcus aureus. Staphylococcus aureus merupakan patogen utama pada manusia yang bersifat invasif. Pengobatan Staphylococcus aureus dapat menggunakan golongan penisilin, golongan sefalosporin, vankomisin, dan eritromisin. Obat tersebut mempunyai efek samping dan mahal, sehingga masyarakat mulai tertarik untuk memanfaatkan tanaman tradisional sebagai obat, salah satunya temulawak. Temulawak diduga dapat memberikan efek antimikroba karena memiliki kandungan zat aktif berupa minyak atsiri, yang bekerja dengan cara merusak membran sitoplasma. Penelitian ini ingin membuktikan efek antimikroba ekstrak rimpang temulawak terhadap pertumbuhan Staphylococcus aureus dengan menggunakan true experiments Post test Only Control Group Design. Metode yang dipakai adalah dilusi tabung dengan 8 konsentrasi ekstrak rimpang temulawak:100\%, 50\%, 25\%, 12.5\%, 6.25\%, 3.125\%, 1.56\%, 0.78\% dan 2 kontrol (kontrol bahan dan kontrol kuman). Analisa data menggunakan one way ANOVA, korelasi, dan regresi. Hasil penelitian KHM (Kadar Hambat Minimum) tidak dapat ditentukan karena semakin tinggi konsentrasi ekstrak rimpang temulawak warna dalam tabung semakin keruh, sedangkan KBM (Kadar Bunuh Minimum) pada konsentrasi 6.25\%. Hasil uji one way ANOVA menunjukkan adanya perbedaan yang bermakna antar perlakuan $(p=0.000)$. Semakin tinggi konsentrasi ekstrak rimpang temulawak, semakin besar kemampuan menghambat dan membunuh bakteri Staphylococcus aureus ( $\mathrm{r}$ $=-0.788)$. Pemberian konsentrasi ekstrak rimpang temulawak berpengaruh terhadap penurunan jumlah koloni bakteri Staphylococcus aureus per $\mathrm{ml}(106)(\mathrm{R} 2=62,1 \%)$. Ekstrak rimpang temulawak mempunyai efek antimikroba terhadap pertumbuhan Staphylococcus aureus.
\end{abstract}

\begin{abstract}
The Antimicrobial Effect of Curcuma xanthorriza Extract To Growth of Staphylococcus aureus. Staphylococcus aureus is prime pathogen for buman that have invasive character. Drugs of choice for Staphylococcus aureus are penicillin, cephalosporin, vancomycin, and erythromycin. Antibiotics have side effects and expensive, so people are interested to use traditional medicines, one of the traditional medicines is curcuma xanthorriza. Curcuma xanthorriza is supposed to have antimicrobial effect because it is contains atsiri oil as active substance, it is work by damage to cytoplasma membrane. This research to proof the antimicrobial effect of curcuma xanthorriza extract to growth of Staphylococcus aureus with using Post Test Only Control Group Design. Method being used is tube dilution test with 8 curcuma xanthorriza concentrations: $100 \%, 50 \%, 25 \%, 12.5 \%, 6.25 \%, 3.125 \%, 1.56 \%, 0.78 \%$ and 2 controls (material control and germ control). Analysis of data using one way ANOVA, correlation, and regression. MIC (Minimal Inbibitory Concentration) from the experiment can not be certained because extract used bigher concentration, the extract colour more turbid, while MBC (Minimal Bactericidal Concentration) is on 6.25\% concentration. One way ANOVA test shows significant difference between curcuma xanthorriza extract concentration $(p=0.000)$. Higher curcuma xanthorriza extract concentration, higher ability to inbibit and bactericid Staphylococcus aureus $(r=-0.788)$. Curcuma xanthorriza extract influences reduce large amount of Staphylococcus aureus colony $(\mathrm{R} 2=62,1 \%)$. Curcuma xanthorriza extract have antimicrobial effect to growth of Staphylococcus aureus.
\end{abstract}

Key words: the strength of M. Quadrisep femoris, postural balance disorder

\section{PENDAHULUAN}

Bakteri Staphylococcus, merupakan sebagian dari flora normal pada kulit manusia, saluran pernafasan dan saluran pencernaan makanan. Pada 6,6\% dari bayi yang berumur 1 hari telah dapat ditemukan Staphylococcus di hidungnya, $50 \%$ pada umur 2 hari, $62 \%$ pada umur 3 hari, dan $88,8 \%$ pada umur 4-8 hari. Genus Staphylococcus sedikitnya memiliki 30 spesies. Tiga spesies Staphylococcus yang berkaitan dengan medis adalah Staphylococcus aureus, Staphylococcus epidermidis, Staphylococcus saprophyticus.
Staphylococcus aureus merupakan patogen utama pada manusia yang bersifat invasif, sehingga dapat menyebabkan terjadinya furunkel, karbunkel, sistitis, pielitis, bahkan dapat pula menyebabkan terjadinya septikemia, endokarditis, meningitis, abses serebri, osteomielitis dan pneumonia (Sujudi, 1994).

Pengobatan Staphylococcus aureus dapat menggunakan golongan penisilin, golongan sefalosporin, vankomisin, dan eritromisin. Beberapa galur dari Staphylococcus aureus menghasilkan enzim penisilinase sehingga resisten tehadap 
golongan obat penisilin. Bakteri yang sudah resisten tersebut masih sensitif terhadap golongan penisilin yang tahan terhadap enzim penisilinase, misalnya metisilin dan oksasilin. Meskipun demikian, juga telah dikenal galur Staphylococcus yang resisten terhadap metisilin yang disebut Methicillin Resistant Staphylococcus aureus (MRSA) (Dzen dkk, 2003).

Epidemi Methicillin resistant Staphylococcus aureus (MRSA) ditemukan pertama kali di Amerika Serikat pada tahun 1968, dan sampai sekarang masih menjadi masalah utama infeksi nosokomial. Dalam beberapa tahun terakhir, insiden infeksi MRSA terus meningkat di berbagai belahan dunia. Di Asia, prevalensi infeksi MRSA kini mencapai 70\%. Sementara di Indonesia pada 2006 prevalensinya 23,5\% (Andra, 2007). Meskipun bakteri ini memiliki tingkat kekebalan yang cukup tinggi, namun tetap dapat diobati dengan antibiotika seperti vankomisin, teicopanin, dan linezolid. Khusus untuk vankomisin, sejauh ini merupakan antibiotik yang paling banyak digunakan untuk MRSA (Triana, 2008). Namun harga obatobatan tersebut relatif mahal, dan memiliki efek samping seperti reaksi alergi dan gangguan gastroistestinal. Oleh karena itu, untuk menghindari efek samping dari penggunaan obatobat tersebut, saat ini masyarakat mulai tertarik untuk memanfaatkan tanaman tradisional sebagai obat, karena dipandang lebih murah, mudah di dapat, dan lebih aman, salah satunya adalah temulawak (Oei Ban Liang, 1992).

Temulawak merupakan satu dari 19 jenis temu-temuan keluarga Zingiberaceae yang paling banyak digunakan sebagai bahan baku obat tradisional. Tanaman ini tumbuh liar di hutan hutan, ditanam di ladang dan pekarangan rumah (Suranto, 2001). Temulawak diduga dapat memberikan efek antimikroba karena kandungan bahan aktif berupa minyak atsiri. Salah satu unsur minyak atsiri yaitu terpenoid yang diduga melibatkan pemecahan membran oleh komponen-komponen lipofilik. Kandungan lain adalah Phenol, diduga bersifat toksik terhadap bakteri melalui inhibisi enzim (Cowan, 1999).

Penelitian terdahulu telah membuktikan bahwa temulawak mempunyai sifat fungistatik terhadap beberapa jamur golongan dermatophyta, dan bersifat bakteriostatik pada mikroba jenis Salmonella (Afifah, 2003), Pseudomonas pyogenes Staphylococcus aureus, dan anti fungi terhadap Mycrosporum gypseum. Aktivitas $1 \mathrm{ml}$ minyak atsiri pada Pseudomonas pyogenes sebanding dengan $0,3 \mathrm{mg}$ tetrasiklin, dan aktivitas $1 \mathrm{ml}$ minyak atsiri pada Staphylococcus aureus sebanding dengan 29,2658 mg tetrasiklin. Diduga kandungan minyak atsiri pada rimpang temulawaklah yang bersifat sebagai antibakteri (Afrida, 1993).

Penelitian lain membuktikan bahwa minyak atsiri laos dapat menghambat Bacillus subtilis dan Staphylococcus aureus pada konsentrasi 8\% dengan diameter zona inhibisi masing masing $10 \mathrm{~mm}$ dan $7 \mathrm{~mm}$ (Yuharmen, 2002). Dalam rangka usaha pengembangan dan pemanfaatan obat tradisional dan untuk mengetahui apakah pengobatan tradisional lebih efektif dari obat yang sudah terbukti dapat membunuh Staphylococcus aureus, maka perlu dilakukan penelitian. Pada penelitian ini peneliti akan meneliti aktifitas antimikroba ekstrak rimpang temulawak terhadap bakteri Staphylococcus aureus dan dibandingkan dengan vankomisin sebagai antibiotik yang paling banyak digunakan pada MRSA, penisilin dan metisilin sebagai antibiotik yang telah resisten terhadap bakteri Staphylococcus aureus.

\section{BAHAN DAN METODE}

Alat dan bahan yang digunakan yaitu Isolat Staphylococcus aureus,Pewarna Gram (kristal violet, lugol, alkohol $96 \%$, safranin) ,Media perbenihan kosong: NAP dan Nutrient Broth, Bahan Tes koagulase, katalase, Tabung reaksi steril, Ose lengkung, Mikropipet $1 \mathrm{ml}$, Inkubator, Lampu Spirtus, Label, Vortex , Spektrofotometer, Colony counter.

\section{Pembuatan Ekstrak Rimpang Temulawak}

Rimpang temulawak yang akan digunakan dipilih yang tidak busuk atau rusak. Kemudian temulawak dibersihkan dan dicuci bersih lalu diiris tipis-tipis dan dijemur hingga kering. Setelah itu temulawak digiling sehingga diperoleh bentuk bubuk.

Ekstraksi dengan etanol dengan cara bubuk temulawak dibungkus dengan kertas saring dan dimasukkan ke dalam gelas ekstraksi. Ekstraksi dilakukan dengan menggunakan pelarut etanol $96 \%$ dan dibiarkan terendam selama \pm 3 hari. Ekstraksi dilakukan beberapa kali putaran dengan pergantian etanol.

Proses evaporasi yakni, Evaporator dipasang pada tiang permanen agar dapat tergantung dengan kemiringan $30-40^{\circ}$ terhadap meja percobaan, dengan susunan dari bawah ke atas : alat pemanas air, labu penampung, hasil evaporasi, rotary evaporator, dan tabung pendingin spiral . Hasil ekstraksi dipindah kedalam labu pemisah ekstraksi.Labu pemisah ekstraksi dihubungkan dengan bagian bawah evaporator. Tabung pendingin spiral dihubungkan dengan bagian atas evaporator. Labu penampung hasil evaporasi dihubungkan dengan bagian atas evaporator. Tabung pendingin spiral dan pompa vakum dihubungkan dengan selang plastik. Tabung pendingin spiral dan pompa sirkulasi air dingin dihubungkan dengan selang plastik. Pompa sirkulasi air dingin ditempatkan dalam bak yang berisi aquabides. Letakkan satu set alat evaporasi sehingga sebagian labu pemisah ekstraksi terendam aquabides pada pompa sirkulasi air dingin. Rotary evaporator, pompa sirkulasi air dingin, dan pompa vakum dijalankan. Alat pemanas air dinyalakan dan diatur suhunya sekitar $70-80^{\circ} \mathrm{C}$ (sesuai dengan titik didih etanol) sehingga hasil ekstraksi dalam labu pemisah ekstraksi mendidih dan pelarut etanol menguap. Hasil penguapan etanol dikondensasi menuju labu penampung etanol sehingga tidak tercampur dengan hasil evaporasi, sedangkan uap lain tersedot oleh pompa vakum Proses evaporasi dilakukan hingga volume kecil hasil ekstraksi berkurang dan

menjadi kental. Setelah kental proses evaporasi dihentikan dan hasil evaporasi diambil. Hasil evaporasi ditampung dalam cawan penguap kemudian dioven selama \pm 2 jam pada suhu $80^{\circ} \mathrm{C}$ untuk menguapkan pelarut yang tersisa, sehingga didapatkan hasil ekstrak rimpang temulawak 100\% . Ekstrak kemudian ditimbang dengan neraca analitik.

\section{Identifikasi Bakteri Staphylococcus aureus}

Untuk memastikan bahwa koloni yang tumbuh adalah Staphylococcus aureus maka dilakukan serangkaian tes konfirmasi. Tes yang dilakukan antara lain: pewarnaan gram, tes katalase, dan tes koagulase. 
Uji Efektifitas Kepekaan Larutan Ekstrak Rimpang Temulawak Terhadap

\section{Staphylococcus aureus.}

Disediakan 10 tabung reaksi steril; tabung 1, tabung 2 , tabung 3 , tabung 4 , tabung 5 , tabung 6 , tabung 7 , tabung 8, tabung 9, tabung10. Masing-masing perlakuan ekstrak rimpang temulawak 8 konsentrasi dan 2 tabung kontrol. Tabung 1 (Y) diisi dengan $2 \mathrm{ml}$ ekstrak rimpang temulawak tanpa penambahan bakteri Staphylococcus aureus, sehingga konsentrasi ekstrak rimpang temulawak adalah $100 \%$. Masukkan Nutrient broth $1 \mathrm{ml}$ ke dalam tabung 3 sampai dengan 9 .Masukkan larutan ekstrak rimpang temulawak $1 \mathrm{ml}$ kedalam tabung 2 dan 3. Campurlah hingga rata larutan Nutrient broth dan ekstrak rimpang temulawak pada tabung 3, kemudian pindahkan sebanyak $1 \mathrm{ml}$ ke dalam tabung 4. Campurlah hingga rata larutan pada tabung 4, kemudian pindahkan sebanyak $1 \mathrm{ml}$ ke dalam tabung 5 . Campurlah hingga rata larutan pada tabung 5, kemudian pindahkan sebanyak $1 \mathrm{ml}$ ke dalam tabung 6. Campurlah hingga rata larutan pada tabung 6 , kemudian pindahkan sebanyak $1 \mathrm{ml}$ ke dalam tabung 7. Campurlah hingga rata larutan pada tabung 7, kemudian pindahkan sebanyak $1 \mathrm{ml}$ ke dalam tabung 8 . Campurlah hingga rata larutan pada tabung 8 , kemudian pindahkan sebanyak $1 \mathrm{ml}$ ke dalam tabung 9. Pada tabung 9, setelah tercampur rata, larutan dibuang sebanyak $1 \mathrm{ml}$. Tabung $10(\mathrm{X})$ diisi dengan $2 \mathrm{ml}$ bakteri Staphylococcus aureus dengan konsentrasi 106 bakteri/ml tanpa pencampuran dengan ekstrak rimpang temulawak sebagai kontrol bakteri. Perbenihan cair bakteri dimasukkan pada tabung 2-6, masing-masing sebanyak 1 ml. Tabung reaksi 1-10 diinkubasikan pada suhu 37?C selama 18-24 jam. Keesokan harinya, semua tabung dikeluarkan dari inkubator. Akan didapatkan Kadar Hambat Minimal dengan cara melihat kejernihan tabung. Untuk mengetahui Kadar Bunuh Minimal, maka dilakukan streaking pada Nutrient

Agar Plate (NAP) dimulai dari tabung yang tidak menampakkan kekeruhan. Kemudian diinkubasi pada suhu 37?C selama 18-24 jam. Keesokan harinya diamati nilai Kadar Bunuh Minimal dari ekstrak rimpang temulawak terhadap bakteri Staphylococcus aureus dan dilakukan penghitungan koloni bakteri dengan colony counter.

Data yang diperoleh yaitu data konsentrasi ekstrak rimpang temulawak dan jumlah koloni bakteri. Analisis yang digunakan adalah uji anova,uji korelasi, dan uji regresi. Uji anova satu arah bertujuan untuk menganalisis hubungan antara jumlah koloni bakteri dengan konsentrasi ekstrak rimpang temulawak untuk menunjukkan adanya perbedaan pada dua kelompok atau Ditanam pada NAP yang sudah di streaking bakteri Staphylococcus aureus Inkubasi selama 18-24 jam, pada suhu $37^{\circ} \mathrm{C}$. Diukur diameter zona jernih sekitar cakram Vankomisin, Penisilin, Metisilin dan cakram ekstrak rimpang temulawak dibandingkan dengan standart NCCLS (National Committee for Clinical Laboratory Standart), Vankomisin disk $(30 \mu \mathrm{g})$ Setelah ditemukan KHM \& KBM pada langkah II maka konsentrasi ekstrak rimpang temulawak dimasukkan dalam disblank : Penisilin disk (10 U) dan Metisilin disk (5 $\mu \mathrm{g})$ lebih. Uji korelasi digunakan untuk menunjukkan adanya hubungan antara peningkatan konsentrasi ekstrak rimpang temulawak dan penurunan jumlah pertumbuhan koloni bakteri Staphylococcus aureus. Uji regresi digunakan untuk mencari seberapa kuat hubungan yang ada antara peningkatan konsentrasi dan penurunan jumlah koloni bakteri Staphylococcus aureus

\section{HASIL DAN PEMBAHASAN}

Efek Antimikroba Ekstrak Rimpang Temulawak Terhadap Bakteri Staphylococcus aureus.

Tabel 1. Skor Tingkat Kekeruhan yang dihasilkan pada media Nutrient broth oleh koloni bakteri Staphylococcus aureus dalam kelompok konsentrasi ekstrak rimpang temulawak (Curcuma xanthorrhiza)

\begin{tabular}{|c|c|c|c|c|}
\hline No. & Ketompok Petzizuan & $\mathrm{n}$ & $\sum$ stor & Atti \\
\hline 1 & $\begin{array}{c}100 \% \\
\text { (bontrol bahan) }\end{array}$ & 3 & 3 & Sangat keruh \\
\hline 2 & $100 \%$ & 3 & 3 & Sanga beruh \\
\hline 3 & $50 \%$ & 3 & 3 & Sangen beruh \\
\hline 4 & $23 \%$ & 3 & 3 & Sangen beruh \\
\hline 5 & $125 \%$ & 3 & 2 & Keruh \\
\hline 6 & $625 \%$ & 3 & 2 & Keruh \\
\hline 7 & $3,125 \%$ & 3 & I & Agak keruh \\
\hline 8 & $156 \%$ & 3 & $T$ & Agak keruh \\
\hline 9 & $0,78 \%$ & 3 & $T$ & Agak kenuh \\
\hline 10 & $\begin{array}{c}0 \% \\
\text { (koctrol buman) }\end{array}$ & 3 & 1 & Agak kenuh \\
\hline \multicolumn{5}{|c|}{ Kemeanumin } \\
\hline $\begin{array}{l}0 \\
1 \\
2 \\
3 \\
0\end{array}$ & 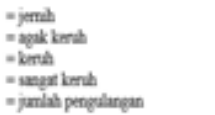 & & & \\
\hline
\end{tabular}

Hasil pengamatan pada uji dilusi tabung setelah diinkubasi selama 18-24 jam pada suhu 37?C dapat diketahui bahwa hasil uji dilusi pada konsentrasi ekstrak rimpang temulawak 100\% sampai dengan 0\% menunjukkan tingkat kekeruhan yang semakin menurun. Namun tingkat kekeruhan dalam tabung tidak menunjukkan semakin banyaknya bakteri Staphylococcus aureus, tetapi hal ini disebabkan warna asli dari ekstrak rimpang temulawak yaitu kuning sehingga sulit bagi kita untuk menafsirkan derajat kekeruhan dalam tabung, sehingga hal tersebut tidak bisa dijadikan dasar penentuan KHM dan KBM dari ekstrak rimpang temulawak terhadap Staphylococcus aureus. Oleh karena itu untuk menentukan KHM dan KBM maka selanjutnya dilakukan konfirmasi dengan penanaman pada media padat NA.

Kadar Bunuh Minimum (KBM) Ekstrak Rimpang Temulawak. Hasil pengamatan pertumbuhan koloni bakteri Staphylococcus aureus pada media NAP(Nutrient Agar Plate) dengan tiap konsentrasi ekstrak rimpang temulawak dapat dilihat pada lampiran 3. Sedangkan hasil perhitungan ratarata jumlah koloni Staphylococcus Aureus per ml (106) dalam berbagai konsentrasi ekstrak rimpang temulawak dapat ditunjukkan pada tabel 2. 
Tabel 2. Pengaruh konsentrasi ekstrak rimpang temulawak terhadap jumlah koloni bakteri Staphylococcus aureus per $\mathrm{ml}\left(10^{6}\right)$

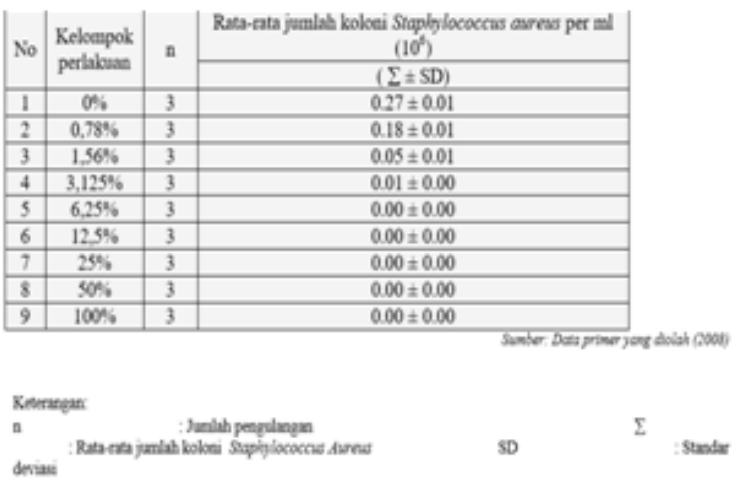

Dari tabel 2 dapat dilihat bahwa rata-rata jumlah koloni bakteri Staphylococcus aureus per $\mathrm{ml}\left(10^{6}\right)$ yang dihasilkan pada NAP berbeda tiap kelompok perlakuan. Hal ini menunjukkan bahwa terdapat perbedaan yang sangat bermakna $(p=0.000)$ pada jumlah koloni bakteri Staphylococcus aureus per $\mathrm{ml}\left(10^{6}\right)$ akibat pengaruh perlakuan dari ke-9 konsentrasi ekstrak rimpang temulawak yang diberikan.

Pada konsentrasi 0\% rata-rata jumlah koloni bakteri Staphylococcus aureus per $\mathrm{ml}\left(10^{6}\right)$ sebesar $0.27 \pm 0.01$. Jumlah rata-rata koloni Staphylococcus aureus per ml (106) terus menurun pada konsentrasi $0,78 \%, 1,56 \%$, dan 3,125\% . Sedangkan mulai konsentrasi 6,25\% sampai konsentrasi $100 \%$ tidak didapatkan pertumbuhan koloni Staphylococcus aureus per ml (106). Pada penelitian ini KBM ekstrak rimpang temulawak terhadap koloni Staphylococcus aureus, ditentukan pada konsentrasi 6,25\%. Terjadinya penurunan jumlah koloni Staphylococcus aureus per $\mathrm{ml}\left(10^{6}\right)$ dengan peningkatan konsentrasi ekstrak rimpang temulawak $(\mathrm{p}=$ $0.000, \mathrm{r}=0.788$ ) menunjukkan adanya hubungan yang bermakna negatif antara ke-9 konsentrasi ekstrak rimpang temulawak terhadap jumlah koloni Staphylococcus aureus per $\mathrm{ml}$ (106). Artinya semakin tinggi konsentrasi ekstrak rimpang temulawak relatif menurunkan jumlah koloni Staphylococcus aureus.

Besarnya pengaruh konsentrasi ekstrak rimpang temulawak terhadap jumlah koloni Staphylococcus aureus per $\mathrm{ml}\left(10^{6}\right)$ didapat nilai koefisien determinasi (R2) sebesar $(\mathrm{p}=0.000, \mathrm{R} 2=62,1 \%)$. Artinya bahwa $62,1 \%$ jumlah koloni Staphylococcus aureus per $\mathrm{ml}\left(10^{6}\right)$ dipengaruhi oleh konsentrasi ekstrak rimpang temulawak. Sedangkan sisanya akan dijelaskan oleh variabel-variabel yang tidak dibahas dalam penelitian ini.

Adanya pengaruh yang cukup bermakna dari hasil penelitian mengenai pengaruh ke-9 konsentrasi ekstrak rimpang temulawak terhadap jumlah koloni Staphylococcus aureus per ml.

Perbandingan Efek Antimikroba Ekstrak Rimpang Temulawak dengan Vankomisin, Penisilin, dan Metisilin Terhadap Bakteri Staphylococcus aureus Diameter zona inhibisi pada biakan Staphylococcus aureus dengan vankomisin $(30 \mu \mathrm{g})$ adalah $18 \mathrm{~mm}$, yang masih sensitif terhadap bakteri Staphylococcus aureus karena mempunyai nilai lebih dari $12 \mathrm{~mm}$ (NCCLS). Diameter zona inhibisi pada biakan Staphylococcus aureus dengan Penisilin (10U) adalah $41 \mathrm{~mm}$ yang masih sensitif terhadap bakteri Staphylococcus aureus karena mempunyai nilai lebih dari $29 \mathrm{~mm}$ (NCCLS), dan diameter zona inhibisi pada biakan Staphylococcus aureus dengan metisilin $(5 \mu \mathrm{g})$ adalah $30 \mathrm{~mm}$ yang masih sensitif terhadap bakteri Staphylococcus aureus karena mempunyai nilai lebih dari $14 \mathrm{~mm}$ (NCCLS). Sedangkan diameter zona inhibisi ekstrak rimpang temulawak tidak bisa dikatakan resisten, intermediet, atau sensitif karena tidak mempunyai nilai standart zona inhibisi.

Tabel 3. Perbandingan zona inhibisi antimikroba ekstrak rimpang temulawak dengan vankomisin, penisilin, dan metisilin terhadap bakteri Staphylococcus aureus

\begin{tabular}{|c|c|c|c|c|}
\hline \multirow{2}{*}{ Antimikroba } & \multirow{2}{*}{$\begin{array}{c}\text { Diameter zona } \\
\text { inhibisi (mm) }\end{array}$} & \multicolumn{3}{|c|}{$\begin{array}{c}\text { Zona inhibisi menurut NCCLS (National } \\
\text { Committee for Clinical Laboratory Standart) }\end{array}$} \\
\cline { 3 - 5 } & & Resisten & Intermediet & Sensitif \\
\hline Vankomisin & 18 & $\leq 9$ & $10-11$ & $\geq 12$ \\
\hline Penisilin & 41 & $\leq 20$ & $21-28$ & $\geq 29$ \\
\hline Metisilin & 30 & $\leq 9$ & $10-13$ & $\geq 14$ \\
\hline $6,25 \%$ & 14 & - & - & - \\
\hline $3,125 \%$ & 11 & - & - & - \\
\hline $1,56 \%$ & 8 & - & - & - \\
\hline
\end{tabular}

Berdasarkan hasil penelitian, KHM (Kadar Hambat Minimum) ekstrak rimpang temulawak terhadap bakteri Staphylococcus aureus tidak dapat dinilai, karena semakin tinggi konsentrasi ekstrak rimpang temulawak maka warna dalam tabung akan semakin keruh, namun tingkat kekeruhan tidak menunjukkan semakin banyaknya bakteri Staphylococcus aureus, tetapi hal ini disebabkan warna asli dari ekstrak rimpang temulawak yaitu kuning. Kadar Bunuh Minimum (KBM) pada penelitian ini adalah 6,25\% yang ditandai dengan adanya penurunan pertumbuhan bakteri sampai 99,9\% dari jumlah koloni bakteri Staphylococcus aureus pada original inoculum.

Penelitian ini membuktikan bahwa ekstrak rimpang temulawak dapat menghambat dan membunuh bakteri Staphylococcus aureus $(p=0.000)$. Hal ini kemungkinan karena adanya kandungan ekstrak rimpang temulawak Curcuma xanthorrhiza) yaitu minyak atsiri dan kurkumin. Rimpang temulawak mengandung zat kuning kurkumin, minyak atsiri, pati, protein, lemak (fixed oil), selulosa, dan mineral (Afifah, 2003). Berkhasiatnya temulawak diduga karena adanya kandungan minyak atsiri dan kurkumin. Minyak atsiri temulawak adalah cairan berwarna kuning/jingga yang mempunyai rasa yang tajam dengan bau khas aromatik. Minyak atsiri mengandung beberapa zat, yakni seskuiterpen, $\alpha$-curcumene, $\alpha$-curcumene, 1 sikloisoprenmyrcene, zingiberene, xanthorrhizol, turunan lisabolen, epolisidbisakuron, bisakuron A, bisakuron B, bisakuron C, kentoseskuiterpen, $\alpha$-turmeron, $\alpha$-atlanton, germakron, monoterpen, sineol, d-borneol, d- $\alpha$-phellandrene, dan dcamphene (Afifah, 2003), terpenoid, phenol (Naim, 2004).

Kandungan minyak atsiri yang diduga bekerja pada bakteri adalah terpenoid, phenol. Terpenoid merupakan metabolit sekunder yang memberikan bau-bauan pada tumbuhan dan diduga memiliki kemampuan secara aktif melawan bakteri, jamur, dan protozoa. Terpenoid yang 
disebut dengan petalostemumol memperlihatkan aktifitas terhadap Bacillus subtilis, dan Candida albicans (Naim, 2004). Terpenoid aktif melawan bakteri, tetapi mekanisme antibakterial terpenoid masih belum benar-benar diketahui. Aktifitas antibakteri terpenoid diduga melibatkan pemecahan membran oleh komponen-komponen lipofilik (Cowan, 1999).

Phenol diduga memiliki mekanisme toksisitas terhadap bakteri melalui inhibisi enzim oleh bahan-bahan yang teroksidasi, kemungkinan reaksi dengan gugus sulfhidril atau melalui interaksi yang lebih tidak spesifik dengan protein mikroorganisme (Cowan, 1999). Kurkumin (C21H20O6) adalah suatu pigmen kuning (Health notes inc, 2002) yang mudah larut dalam eter klorofom dan alkohol serta sedikit larut dalam benzene. Kurkumin telah banyak diekstrak dan diteliti untuk kepentingan medis, salah satunya adalah sebagai antibakteri(Ram Trades, 2003). Kurkumin memiliki efek fototoksik terhadap bakteri. Ketika terkena cahaya, kurkumin bertindak sebagai bahan antibakteri dengan memproduksi hidrogen peroksida yang dapat menyebabkan kerusakan membran sitoplasma (Dahl et al, 1989).

Terpenoid, phenol, dan hidrogen peroksida diduga bekerja pada bakteri dengan cara merusak membran sitoplasma, hal ini mengakibatkan ion anorganik yang penting (trace element yaitu $\mathrm{Fe}, \mathrm{Cu}, \mathrm{Zn}$ ), nukleotida, koenzim, dan asam amino merembes keluar sel, serta mencegah masuknya bahan-bahan makanan atau nutrisi yang diperlukan bakteri untuk menghasilkan energi (Wheeler and Volk, 1993). Membran sitoplasma bertugas melaksanakan metabolisme energi dalam sel-sel prokariotik. Sehingga, jika membran sitoplasma rusak maka metabolisme energi tidak akan berlangsung, hal ini menyebabkan ketidakmampuan sel untuk tumbuh yang akhirnya menyebabkan kematian sel.

Penelitian ini menggunakan ekstrak rimpang temulawak yang merupakan salah satu cara untuk mendapatkan bahan aktif yang terkandung dari rimpang temulawak. Namun, kandungan bahan aktif dari rimpang temulawak yang dihasilkan adalah ekstrak kasar dimana masih banyak bahan aktif yang terkandung dalam ekstrak rimpang temulawak. Sehingga belum dapat diketahui secara pasti bahan aktif lain yang juga mempunyai daya antimikroba terhadap Staphylococcus aureus atau bakteri lain. Selain itu perlu dilakukan penelitian lanjutan untuk mengetahui bahwa bahan aktif yang terdapat dalam ekstrak rimpang temulawak mekanisme kerjanya di membran sitoplasma.

Penelitian terdahulu telah membuktikan bahwa temulawak mempunyai sifat fungistatik terhadap beberapa jamur golongan dermatophyta, dan bersifat bakteriostatik pada mikroba jenis Salmonella (Afifah, 2003). Pseudomonas pyogenes, dan anti fungi terhadap Mycrosporum gypseum. Diduga kandungan minyak atsiri pada rimpang temulawaklah yang bersifat sebagai antibakteri(Afrida, 1993).

Hasil penelitian menunjukkan bahwa semakin tinggi konsentrasi ekstrak rimpang temulawak (Curcuma xanthorrhiza) yang diberikan, maka semakin besar kemampuan menghambat dan membunuh bakteri Staphylococcus aureus $(p=0.000, r=-0.788)$ yang ditandai dengan semakin sedikitnya jumlah koloni bakteri Staphylococcus aureus yang tumbuh dalam NAP. Hal ini menunjukkan bahwa pemberian konsentrasi ekstrak rimpang temulawak berpengaruh terhadap penurunan jumlah koloni bakteri Staphylococcus aureus per ml (106) $(\mathrm{p}=0.000$, $\mathrm{R} 2=62,1 \%)$. Hal ini sesuai dengan penjelasan dari Pelezar dan Chan (1998) mengenai beberapa hal yang dapat mempengaruhi zat antimikroba, antara lain konsentrasi zat antimikroba, dimana pada umumnya semakin tinggi konsentrasi suatu zat maka semakin tinggi pula daya antimikrobanya. Selain itu juga dipengaruhi oleh kandungan senyawa antimikroba, jumlah mikroorganisme, suhu, adanya bahan organik, dan keasaman atau kebasahan $(\mathrm{pH})$.

Pengobatan Staphylococcus aureus dapat menggunakan golongan penisilin, golongan sefalosporin, vankomisin, dan eritromisin. Beberapa galur dari Staphylococcus aureus menghasilkan enzim penisilinase sehingga resisten tehadap golongan obat penisilin. Bakteri yang sudah resisten tersebut masih sensitif terhadap golongan penisilin yang tahan terhadap enzim penisilinase, misalnya metisilin dan oksasilin. Meskipun demikian, juga telah dikenal galur Staphylococcus yang resisten terhadap metisilin yang disebut Methicillin Resistant Staphylococcus aureus (MRSA) (Dzen dkk, 2003). Meskipun bakteri ini memiliki tingkat kekebalan yang cukup tinggi, namun tetap dapat diobati dengan antibiotika seperti vankomisin, teicoplanin, dan linezolid. Khusus untuk vankomisin, sejauh ini merupakan antibiotik yang paling banyak digunakan untuk MRSA (Triana, 2008).

Hasil penelitian ini ternyata kontradiktif dengan survey nasional Amerika yang menyatakan bahwa Staphylococcus aureus telah resisten terhadap penisilin dan metisilin (Rubin, 1999), dan vankomisin merupakan antibiotik pilihan yang digunakan untuk MRSA. Pada penelitian ini penisilin dan metisilin masih sangat sensitif di bandingkan dengan vankomisin. Hal ini menunjukkan bahwa bakteri Staphylococcus aureus yang digunakan dalam penelitian ini masih sensitif terhadap penisilin dan metisilin.

Diameter zona inhibisi pada biakan Staphylococcus aureus dengan konsentrasi ekstrak rimpang temulawak 6,25\% adalah $14 \mathrm{~mm}$, pada konsentrasi ini zona inhibisi sebesar 77,8\% jika dibandingkan dengan vankomisin (18 $\mathrm{mm}$ ), zona inhibisi sebesar 34,15\% jika dibandingkan dengan penisilin $(41 \mathrm{~mm})$, dan zona inhibisi sebesar 46,7\% jika dibandingkan dengan metisilin $(30 \mathrm{~mm})$. Namun zona inhibisi ekstrak rimpang temulawak tidak bisa dikatakan resisten, intermediet, atau sensitif karena tidak mempunyai nilai standart zona inhibisi. Secara keseluruhan zona inhibisi dari konsentrasi ekstrak rimpang temulawak yang telah diuji $(6.25 \%, 3.125 \%, 1,56 \%)$, masih lebih rendah dibandingkan dengan zona inhibisi antimikroba uji ((vankomisin $(30 \mu \mathrm{g})$, penisilin (10U), dan metisilin $(5 \mu \mathrm{g})$. Rendahnya kemampuan menghambat bakteri uji (Staphylococcus aureus) pada ekstrak rimpang temulawak dibandingkan antimikroba uji diduga karena perbedaan mekanisme kerja ekstrak rimpang temulawak atau antimikroba pada bakteri Staphylococcus aureus. Vankomisin, penisilin, dan metisilin bekerja dengan menghambat reaksi paling dini dari sintesis dinding sel. Oleh karena tekanan osmotik dalam sel bakteri lebih tinggi daripada diluar sel maka kerusakan dinding sel bakteri akan menyebabkan terjadinya lisis, yang merupakan efek bakterisid 
(Setiabudy, 1995). Sedangkan ekstrak rimpang temulawak diduga bekerja dengan merusak membran sitoplasma, hal ini dapat mengakibatkan keluarnya bahan metabolit dari dalam sel, terjadinya pengendapan protein, inaktifasi enzim bakteri, menghambat masuknya bahan-bahan makanan atau nutrisi yang diperlukan bakteri untuk menghasilkan energi (Wheeler and Volk, 1993).

\section{SIMPULAN}

KHM (Kadar Hambat Minimum) ekstrak rimpang temulawak tidak dapat dinilai sebab semakin tinggi konsentrasi ekstrak rimpang temulawak maka ekstrak akan semakin keruh, dan KBM (Kadar Bunuh Minimum) ekstrak rimpang temulawak terdapat pada konsentrasi 6.25\%. Ekstrak rimpang temulawak (Curcuma xanthorrhiza) memiliki daya antimikroba terhadap bakteri Staphylococcus aureus ( $\mathrm{p}=$ 0.000). Semakin tinggi konsentrasi ekstrak rimpang temulawak, semakin menekan pertumbuhan bakteri Staphylococcus aureus ( $\mathrm{p}=0.000, \mathrm{r}=-0.788)$. Hal ini menunjukkan bahwa pemberian konsentrasi ekstrak rimpang temulawak berpengaruh terhadap penurunan jumlah koloni bakteri Staphylococcus aureus per $\mathrm{ml}(106)(\mathrm{p}=0.000, \mathrm{R} 2=62,1 \%)$

\section{DAFTAR PUSTAKA}

Afifah, E. \& Tim Lentera. 2003. Khasiat Dan Manfaat Temulawak Rimpang Penyembuh Aneka Penyakit. PT Agromedia Pustaka, Jakarta. Hal: 2-3, 7-10,

Afrida, Yulinah, E.S. \& Gana, A.S. 1993 Detail Penelitian Obat Bahan Alam. (Online). (http://bahanalam.fa.itb.ac.id, diakses: 05 Maret 2008).

Andra. 2007. 4th Symposium of Indonesia Antimicrobial Resistance Watch (IARW). (Online).(http:// www.cdph.ca.gov/healthinfo/discond/Documents/ CAMRSAF orAthletes.pdf, diakses 03 April 2008).

Anonymous. 2004. Khasiat dan Kegunaan Temulawak. (Online). (http://www. iptek.net.id/ind/pd_tanobat/ view. php?mnu=2\&id=129, diakses 05 Maret 2008)

Anonymous. 2002. Obat tradisional (Curcuma xanthorrhiza Roxb.). (http://www. balittro.go.id/includes/ Temulawak.pdf, diakses 28 Maret 2008).

Baron, E. J., Peterson, L. R., Finegold Y. M. 1994. Bailey \& Scott's Diagnostic Microbiology, Ninth Edition. Mosby. United State of America

Cowan, Marjorie Murphy. 1999. Plant Products as Antimicrobial Agents. Clinical Microbiology Reviews, (Online), Vol. 12, No. 4, (http://www.emr.org/egi/reprint/12/ $4 / 154$ ? $\mathrm{m}$ ax to $\mathrm{show}=\&$ HITS $=10 \&$ hits $=10 \&$ RESULTFORMAT $=$ Fulltext $=$ Planta ntimicrobial\& searchid, diakses 15 April 2008).

Dahl, T.A. \& Aureli, P. 1989. Photokilling of Bacteria by The Natural Dye Curcumin. Center for Photochemical Science Bowling Green State University, Ohio. Hal: 361

Dalimarta, Setiawan. 2005. Atlas Tumbuhan Obat Indonesia, (Online), (http://www.pdpersi. co.id//pdpersi/ news/alternatif. php3?id=1028, diakses 28 Maret 2008).

Dwijoseputro, D. 1994. Dasar-Dasar Mikrobiologi. Djambatan. Jakarta. Hal: 112

Dzen, S.M., Roekistiningsih, Santoso, S., \& Winarsih, S. 2003. Bakteriologi Medik. Bayumedia Publising.Malang.
Hal:16-22, 122-123, 134,139

Erwin M. 2005. A Short Chemystry Lesson on Essential Oils. (Online), (http://www.aroma market.com/ chemistry.htm. diakses 03 April 2008).

Gupte, Satish MD. 1990. Mikrobiologi Dasar Edisi Ketiga. Binarupa Aksara. Jakarta. Hal: 180

Hart, Tony, \& Paul, Shears. 1997. Atlas Berwarna Mikobiologi Kedokteran. Hipokrates. Jakarta. Hal: 81

Health notes Inc.2002.Turmeric. (Online), (http:// myustompak.com/heath notes/Herb/Turmeric-htm, diakses 15 April 2008)

Hendrik, S.B. 2005. Antimikroba. (http:// www.fkg.unair.ac.id/filer/ANTIMIKROBA.pdf , diakses 03 April 2008)

Jawetz, Melnick, \& Adelberg. 2005. Mikrobiologi Kedokteran Edisi 21. EGC. Jakarta. Hal: 211-215

Kunardi, L. 1995. Golongan Tetrasiklin dan Kloramenikol. Dalam Setiabudi, R (Ed), Farmakologi dan Terapi. Fakultas Kedokteran Universitas Indonesia. Jakarta. Hal:633-634

Lin S.C. 1995. Protective and Therapeutic Effects of Curcuma xanthorrhiza on Hepatotoxin-induced Liver Damage. (Online), (http://www.pubmed.gov, diakses 28 Maret 2008).

Lukito, H. 1998. Rancangan Penelitian Suatu Pengantar. FKIP. Malang. Hal: 25-27

Mary, J.M., Richard, H.V., \& Pamela, C.C. 2001. Penghambat Sintesis Dinding Sel. Dalam Richard, H.V., \& Pamela, H.V. (Ed), Farmakologi dan Terapi. Fakultas Kedokteran Universitas Indonesia. Jakarta. Hal: 304305

Murray, P.R., Baron, P.E., \& Tenover, F.C. 1999. Manual of Clinical Microbiology 7th Edition. American Society for Microbiology, ASM Press. Washington DC. Hal: $1527-1536$

Naim, R. 2004. Senyawa Antimikroba dari Tanaman, (Online), (http://www.kcm. com/sorotan/ 1265264.htm, diakses 03 April 2008).

Oei Ban Liang. 1992. Pengembangan obat anti-inflamasi dari spesies Curcuma. ITB, Bandung. Hal: 1-

Paimin, F.B., \& Murhananto. 2006. Budidaya, Pengolahan, Perdagangan Jahe Edisi Revisi. Penebar Swadaya. Jakarta.

Pelezar \& Chan. 1998. Dasar-Dasar Mikrbiologi. UI Press. Yakarta. Hal: 452

Ram Trades. 2003. Uses Of Turmeric. (Online), (http:// www.turmeric8m.comluses.html, diakses 15 April 2008)

Rubin RJ. et al. (1999). The economic impact of Staphylococcus infection in New York Hospitals. Emerging Infectious Diseases.; 5: 9-17.

Rukmana, Rahmat. 1995. Temulawak Tanaman Rempah Dan Obat. Kanisius, Yogya. Hal: 14

Setiabudy, R. 1995. Antimikroba lain. Dalam Farmakologi dan Terapi. Fakultas Kedokteran Universitas Indonesia. Jakarta. Hal: 675-676, 682

Shulman, Phair, \& Sommers. 1994. Dasar Biologi dan Klinis Penyakit Infeksi Edisi IV. Gajah Mada University Press. Yogyakarta. Hal: 582

Sudewo, Bambang. 2005. Tanaman Obat Popular Penggempur Aneka Penyakit. Agromedia Pustaka, Jakarta.Hal: 31-32 
Sujudi. 1994. Mikrobiologi Kedokteran Edisi Revisi. Binarupa Aksara. Jakarta. Hal: 104-105,108-109

Sumarsih, Sri. 2003. Mikrobiologi Dasar. (Online). (http:/ /sumarsih07.files.wordpress.com/2007/12/buku-ajarmikrobiologi. pdf, diakses 20 juni 2008)

Suranto, A. 2001. Temulawak Temu Penyembuh Yang Menakjubkan. Buletin APTOI, No. 4, Mei 2001, (Online), (http://mahkotadewa.com/Buletin-Aptoino.4.htm, diakses 03 April 2008). Triana, Nunik. Vankomisin vs MRSA. (Online). (http://www. cdph.ca.gov/healthinfo/discond/Documents/ CAMRSAForAthletes.pdf, diakses 03 April 2008).

Usman, Suwandi. 1992. Resistensi Mikroba Terhadap Antibiotik. (Online), (http://www.kalbe.co.id/files/ cdk/files/14_ResistensiMikrobaterhadapAntibiot ik.pdf/14_Resistensi Mikroba terhadap Antibiotik.html, diakses 15 April 2008

Vincent, H.S. 1995. Penisilin, sefalosporin dan antibiotic betalaktam lainnya. Dalam Yati, H.I (Ed), Farmakologi dan Terapi. Fakultas Kedokteran Universitas Indonesia. Jakarta. Hal: 622-636, 636-640, 675-678 Wheeler \& Volk. 1993. Mikrobilologi Dasar. Erlangga. Jakarta. Hal: 112

Yuharmen. 2002. Uji Aktivitas Antimikroba Minyak Atsiri Dan Ekstrak Metanol Lengkuas (alpinia galanga). (Online), (http:/ www.litbang.depkes.go.id, diakses 20 juli 2008) 